\title{
PENGARUH STRES KERJA TERHADAP KEPUASAN KERJA DENGAN MOTIVASI KERJA SEBAGAI VARIABEL MEDIASI
}

\author{
I Gede Redita Yasa ${ }^{1}$ \\ A.A. Sagung Kartika Dewi \\ ${ }^{1,2}$ Fakultas Ekonomi dan Bisnis Universitas Udayana, Bali, Indonesia \\ email: reditayasagede@yahoo.com
}

\begin{abstract}
ABSTRAK
Kepuasan kerja merupakan suatu keadaan karyawan merasa puas terhadap pekerjaannya. Orang yang mengungkapkan kepuasaan yang tinggi dalam pekerjaannya cenderung lebih produktif, sedangkan orang yang tidak produktif cenderung mengalami stres pada pekerja. Tujuan dari penelitian ini adalah untuk menganalisis pengaruh stres kerja terhadap kepuasan kerja dengan motivasi sebagai variabel mediasi pada Badan Pendapatan Kota Denpasar. Penelitian ini dilakukan pada Badan Pendapatan Daerah Kota Denpasar, jumlah sampel pada penelitian ini adalah 92 orang PNS dengan metode sampling jenuh. Teknik analisis jalur (Path Analysis) digunakan dalam penelitian ini. Berdasarkan hasil analisis penelitian ditemukan bahwa Stres kerja berpengaruh negatif dan signifikan terhadap kepuasan kerja. Stres kerja berpengaruh negatif dan signifikan terhadap motivasi. Motivasi berpengaruh positif dan signifikan terhadap kepuasan kerja. Motivasi mampu memediasi pengaruh stres kerja terhadap kepuasan kerja. Ini berarti bahwa meskipun adanya stres kerja tetapi apabila ditunjang dengan motivasi yang tinggi maka akan timbul kepuasan kerja yang maksimal.
\end{abstract}

Kata Kunci: stres kerja, motivasi, kepuasan kerja

\begin{abstract}
Job satisfaction is a condition where employees feel satisfied with their work. People who express high satisfaction in their work tend to be more productive, while unproductive people tend to experience stress on workers. The purpose of this study was to analyze the effect of work stress on job satisfaction with motivation as an mediation variable on Denpasar City Revenue Agency. This research was conducted at the Denpasar City Regional Revenue Agency, the number of samples in this study were 92 civil servants with saturated sampling method. Path analysis technique is used in this study. Based on the results of the analysis of the study found that job stress has a negative and significant effect on job satisfaction. Job stress has a negative and insignificant effect on motivation. Motivation has a positive and significant effect on job satisfaction. Motivation is able to mediate the influence of work stress on job satisfaction. This means that despite work stress but if supported by high motivation, maximum job satisfaction will arise.
\end{abstract}

Keywords: job stress, motivation, job satisfaction 


\section{PENDAHULUAN}

Kepuasan kerja adalah suatu keadaan karyawan merasa puas terhadap pekerjaannya. Orang yang mengungkapkan kepuasaan yang tinggi dalam pekerjaannya cenderung lebih produktif, mempunyai keterlibatan yang tinggi dan kecil kemungkinannya dalam mengundurkan diri dibandingkan dengan karyawan yang merasakan kepuasaan yang kurang (Sowmya dan Panchanatham, 2011). Kepuasan kerja sangatlah penting sebab karyawan dalam sebuah organisasi merupakan faktor yang paling dominan dalam menentukan berhasil atau tidaknya kegiatan organisasi. Kepuasan kerja karyawan harus diciptakan sebaik - baiknya agar moral kerja, dedikasi, kecintaan dan kedisiplinan kerja tinggi. Dikutip oleh Fredluthans terjemahan Yuwono, (2006:243) menyatakan bahwa kepuasan kerja adalah: Keadaan emosi yang senang atau emosi positif yang berasal dari penilaian pekerjaan atau Pengalaman kerja seseorang. Dewi dan Netra (2015) Stres kerja terhadap kepuasan kerja berpengaruh negatif dan signifikan sesuai dengan pendapat Tukimin (2014), Li Li (2014) berpendapat bahwa pengaruh stress kerja terhadap kepuasan kerja berpengaruh negatif dikarenakan adanya pengembangan karir, stres upah dan imbalan yang menjadi faktor, begitu juga dengan pendapat oleh Mansoor(2011), Adelia dan Mujiati(2016). Sedangkan menurut Hanim(2016) stres kerja terhadap kepuasan kerja berpengaruh positif dan signifikan sesuai dengan pendapat Riaz (2016) dan dan Essiam (2015) yang mengatakan bahwa stres kerja adalah masalah yang sangat substansial di tempat kerja.

Stres kerja merupakan salah satu permasalah serius yang menimpa setiap karyawan di tempat kerjanya (Tunjungsari, 2011). Stres dapat timbul sebagai akibat 
dari tekanan atau ketegangan yang bersumber dari ketidakselarasan antara seseorang dengan lingkungannya. Stres yang dialami oleh karyawan akibat lingkungan yang dihadapinya akan mempengaruhi kinerja dan kepuasan kerjanya, sehingga manajemen perlu untuk meningkatkan mutu lingkungan organisasional bagi karyawan Noviansyah dan Zunaidah, (2011). Menurut Dewi dan Netra (2015) bahwa stress kerja berpengaruh negatif dan signifikan terhadap kepuasan kerja karyawan, menurut Afrizal dkk (2014) dan Ahsan (2009) menunjukkan bahwa stres kerja berpengaruh negatif dan signifikan terhadap kepuasan kerja. Bahri (2013), Iqbal dan Muhammad (2012) juga menunjukkan adanya pengaruh negatif yang signifikan antara stres kerja terhadap kepuasan kerja. Sedangkan penelitian oleh Fadhilah (2010) juga menunjukkan bahwa stres kerja berpengaruh negatif terhadap kepuasan kerja karyawan. Levelina (2015) pengaruh stres kerja terhadap motivasi berpengaruh positif sesuai dengan pendapat Saleem (2010) dan signifikan sedangkan menurut Yuswani(2016) pengaruh stres kerja terhadap motivasi berpengaruh negatif dan tidak signifikan sesuai dengan pendapat Cendhikia dkk. (2016).

Motivasi kerja, Luthans (2011:156) mendefinis ikan bahwa "motivation is a basic psychological process, few would deny that it is the most important focus in micro appproach to organizational behavior. Motivation interacts with and acts in conjunction with other med iating processes and environment ". Robbins dan Judge (2009:209) mengemukakan"motivation as the pro cesses that account for an individual's intensity, direction, and persistence of effort toward attaining goals". Motivasi kerja merupakan pendorong yang akan mewujudkan suatu perilaku guna 
mencapai tujuan kepuasan dirinya, orang mau bekerja untuk memenuhi kebutuhan, baik kebutuhan yang disadari (conscious needs) maupun kebutuhan/keinginan yang tidak disadari (unconscious neeeds). Ayu dan Brahmasari (2008) dalam penelitiannya menyatakan dalam kehidupan berorganisasi aspek motivasi kerja mutlak perlu mendapat perhatian serius dari para manajer. Penelitian lainnya, seperti yang dilakukan oleh Cahyono (2012) menyatakan bahwa motivasi adalah dorongan atau kemauan yang timbul dari diri pegawai untuk melakukan suatu pekerjaan karena adanya keinginan untuk memenuhi kebutuhan. Kartika dan Kaihatu (2010) pengaruh motivasi terhadap kepuasan kerja berpengaruh positif dan signifikan sesuai dengan pendapat Alamsyah (2015) yang menyatakan bahwa motivasi kerja yang tinggi pada karyawan ditandai dengan adanya kepuasan kerja yang tinggi, Nyarko (2014), Jehanzeb (2012) mengatakan bahwa tingkat penghargaan, motivasi dan kepuasan kerja karyawan memiliki kekuatan hubungan di sektor perbankan Arab Saudi., Khalid (2011).

Purba dan Ngatno (2016) variabel motivasi berhasil menjadi variabel pemediasi antara variabel endogen dan eksogen sejalan dengan penelitian yang dilakukan oleh Gunawan (2015) dan Widyawati (2014) bahwa motivasi berhasil menjadi variabel pemediasi, sedangkan menurut Demokrat (2011) dan Jonika (2016) motivasi tidak berhasil menjadi variable pemediasi.

Badan Pendapatan Daerah Kota Denpasar beralamat di Jl. Letda Tantular No. 12 Denpasar. Badan Pendapatan Daerah Kota Denpasar memiliki tujuan yaitu mengkoordinasikan target penerimaan Pendapatan Asli Daerah serta merealisasikannya bersama-sama dengan unit-unit Satuan Kerja Penghasil PAD, 
untuk selanjutnya dapat dipergunakan membiayai belanja Pemerintah Kota Denpasar yang telah ditetapkan. Berikut disajikan data Pendapatan Asli Daerah tahun 2015-2017:

Tabel 1.

Pendapatan Asli Daerah Kota Denpasar Tahun 2015-2017

\begin{tabular}{ccc}
\hline Tahun & Keterangan & PAD $($ Rp) \\
\hline \multirow{2}{*}{2015} & Target & $724,497,965,101.00$ \\
& Realisasi & $776,176,266,472.00$ \\
\multirow{2}{*}{2016} & Target & $740,366,097,386.75$ \\
& Realisasi & $834,296,740,589.23$ \\
& Target & $932,713,422,712.27$ \\
2017 & Realisasi & $85,813,372,950.43$ \\
\hline
\end{tabular}

Sumber: https://pendapatan.denpasarkota.go.id, 2018

Berdasarkan Tabel 1 PAD pada Badan Pendapatan Kota Denpasar tahun 2015-2017 mengalami perubahan yang berfluktuatif. Terkait dengan hasil wawancara dengan pegawai PNS bahwa tahun 2017 mengalami penurunan realisasi PAD yang bersamaan dengan pergantian kepala Badan yang berdampak pada kepuasan kerja, stress, dan motivasi yang dialami pegawai PNS.

Kepuasan kerja yang dialami pegawai salah satunya dapat dilihat dari penempatan posisi pegawai, sedangkan pada Badan Pendapatan Daerah Kota Denpasar ada beberapa penempatan posisi pegawai yang tidak sesuai dengan kemampuannya sehingga ketidakpuasan dirasakan dikalangan beberapa pegawai dalam menyelesaikan tugas. Stres kerja dapat timbul karena adanya tekanan atau desakan waktu dalam bekerja, pada Badan pendapatan kota Denpasar hal ini sering terjadi khususnya pada akhir bulan maupun akhir tahun yaitu pada bidang bagian:

1) Bagian perencanaan dan umum. 2) Bagian keuangan. 3) Bidang pendataan, 
pendaftaran dan penetapan. 4) Bidang pembukuan dan pelaporan. 5) Bidang penagihan dan keberatan.

Kepuasan kerja adalah pandangan karyawan yang menyenangkan atau tidak menyenangkan terhadap pekerjaan mereka Perasaan tersebut akan tampak dari sikap positif karyawan terhadap pekerjaan dan segala sesuatu yang dihadapi di lingkungan kerjanya” (T.Hani Handoko 2001:193). Menurut Wibowo dkk. (2015) Stres kerja berpengaruh negatif dan signifikan terhadap kepuasan kerja. Menurut Tukimin (2014) stres kerja berpengaruh negatif dan signifikan terhadap kepuasan kerja. Menurut Li Li (2014) bahwa pengaruh stress kerja terhadap kepuasan kerja berpengaruh negatif dikarenakan adanya pengembangan karir, stres upah dan imbalan yang menjadi faktor. Riaz (2016), Rizwan (2014) mengatakan bahwa stres kerja adalah masalah yang sangat substansial di tempat kerja.

Teori kepuasan kerja mencoba mengungkapkan apa yang membuat sebagian orang lebih puas terhadap suatu pekerjaan daripada beberapa lainnya. Teori ini juga mencari landasan tentang proses perasaan orang terhadap kepuasan kerja. Ada beberapa teori tentang kepuasan kerja yaitu Two Factor Theory Teori ini menganjurkan bahwa kepuasan dan ketidakpuasan merupakan bagian dari kelompok variabel yang berbeda yaitu motivators dan hygiene factors. Ketidakpuasan dihubungkan dengan kondisi disekitar pekerjaan (seperti kondisi kerja, upah, keamanan, kualitas pengawasan dan hubungan dengan orang lain) dan bukan dengan pekerjaan itu sendiri. Karena faktor mencegah 16 reaksi negatif dinamakan sebagai hygiene atau maintainance factors. Sebaliknya kepuasan ditarik dari faktor yang terkait dengan pekerjaan itu sendiri atau hasil langsung daripada 
seperti sifat pekerjaan, prestasi dalam pekerjaan, peluang promosi dan kesempatan untuk pengembangan diri dan pengakuan. Karena faktor ini berkaitan dengan tingkat kepuasan kerja tinggi dinamakan motivators.

Value Theory Menurut teori ini kepuasan kerja terjadi pada tingkatan dimana hasil pekerjaan diterima individu seperti diharapkan. Semakin banyak orang menerima hasil, akan semakin puas dan sebaliknya. Kunci menuju kepuasan pada teori ini adalah perbedaan antara aspek pekerjaan yang dimiliki dengan yang diinginkan seseorang. Semakin besar perbedaan, semakin rendah kepuasan orang.

Faktor-faktor yang Mempengaruhi Kepuasan Kerja yaitu ada lima faktor yang dapat mempengaruhi kepuasan kerja menurut Kreitner dan kinicki (2001:225) yaitu sebagai berikut: 1) Pemenuhan kebutuhan (Need fulfillment) Kepuasan ditentukan oleh tingkatan karakteristik pekerjaan memberikan kesempatan pada individu untuk memenuhi kebutuhannya. 2) Perbedaan (Discrepancies) Kepuasan merupakan suatu hasil memenuhi harapan. Pemenuhan harapan mencerminkan perbedaan antara apa yang diharapkan dan apa yang diperoleh individu dari pekerjaannya. Bila harapan lebih besar dari apa yang diterima, orang akan tidak puas. Sebaliknya individu akan puas bila menerima manfaat diatas harapan. 3) Pencapaian nilai (Value attainment) Kepuasan merupakan hasil dari persepsi pekerjaan memberikan pemenuhan nilai kerja individual yang penting. 4) Keadilan (Equity) Kepuasan merupakan fungsi dari seberapa adil individu diperlakukan di tempat kerja. 5) Komponen genetik (Genetic components) Kepuasan kerja merupakan fungsi sifat pribadi dan faktor genetik. Hal ini menyiratkan perbedaan 
sifat individu mempunyai arti penting untuk menjelaskan kepuasan kerja disampng karakteristik lingkungan pekerjaan.

Dalam melakukan pekerjaan, seorang pekerja dapat mengalami stress kerja. Greenberg mendefinisikan stres kerja sebagai kombinasi antara sumber-sumber stres pada pekerjaan, karakteristik individual, dan stresor di luar organisasi. David dan Newstrom mendefinisikan stres kerja sebagai suatu kondisi yang mempengaruhi emosi, proses pikiran, dan kondisi fisik seseorang Sementara, Robbins mendefinisikan stres kerja sebagai kondisi yang dinamis di mana seseorang dikonfrontasikan dengan kesempatan, hambatan, atau tuntutan yang berhubungan dengan apa yang diinginkannya dan untuk itu keberhasilannya ternyata tidak pasti (2007:368).

Robbins (2007:375-377) membagi tiga jenis konsekuensi yang ditimbulkan oleh stres kerja: 1) Gejala fisiologis Stres menciptakan penyakit-penyakit dalam tubuh yang ditandai dengan peningkatan tekanan darah, sakit kepala, jantung berdebar, bahkan hingga sakit jantung. 2) Gejala psikologis Gejala yang ditunjukkan adalah ketegangan, kecemasan, mudah marah, kebosanan, suka menunda dan lain sebagainya. Keadaan stres seperti ini dapat memacu ketidakpuasan. 3) Gejala perilaku Stres yang dikaitkan dengan perilaku dapat mencakup dalam perubahan dalam produktivitas, absensi, dan tingkat keluarnya karyawan. Dampak lain yang ditimbulkan adalah perubahan dalam kebiasaan sehari-hari seperti makan, konsumsi alkohol, gangguan tidur dan lainnya.

Indikator stres kerja menurut Salleh, Bakar dan Keong (2008) terbagi atas 4 skala penilaian yaitu: 1) Beban pekerjaan, dapat diukur dari tanggapan responden 
yaitu, terbagi atas tuntutan tugas, tekanan waktu karena deadline pekerjaan, serta adanya pengambilan keputusan yang terlalu banyak. 2) Posisi pekerjaan, dapat diukur dari tanggapan responden, mengenai adanya ketidakpastian dan kurangnya informasi peran dalam pekerjaan serta adanya harapan dalam pekerjaan dan tanggung jawab dalam pekerjaan. 3) Hubungan di tempat kerja, dapat diukur dari tanggapan responden, mengenai hubungan dengan atasan dan hubungan dengan rekan kerja, yang dimaksud adalah terciptanya hubungan yang harmonis terkait dengan lingkungan pekerjaan dengan atasan atau rekan kerja. 4) Pengembangan karir, yang terbagi atas kurangnya keamanan kerja (ketakutan akan adanya mutasi atau perpindahan antar karyawan) dan ketidakcocokan status misalnya: promosi jabatan yang berlebihan, promosi yang kurang dan frustasi karena harus mengejar jenjang karir yang tinggi.

Pengertian Motivasi menurut Robbins dan Judge (2008) motivasi adalah keinginan untuk berusaha sekuat tenaga untuk mencapai tujuan organisasi yang dikondisikan atau ditentukan oleh kemampuan usaha untuk memenuhi suatu kebutuhan individu. Banyak penulis kontemporer juga telah menetapkan konsep motivasi. Motivasi Kerja Karyawan menurut Hodges dan Luthans dalam Handoko (2005) menyatakan bahwa motivasi kerja merupakan proses psikologis melalui keinginan yang belum terpuaskan, yang diarahkan dan didorong ke pencapaian tujuan insentif. Motivasi kerja menurut Stephen P. Robbin (2008) bahwa: Motivasi merupakan proses yang berperan pada intensitas, arah, dan lamanya berlangsung upaya individu ke arah pencapaian tujuan. Teori motivasi terbaik yang diketahui adalah teori hierarki kebutuhan dari Abraham Maslow (Robbins, 2015;128). 
Maslow menyatakan bahwa di dalam diri setiap manusia terdapat hierarki lima kebutuhan yaitu: kebutuhan fisiologis, kebutuhan rasa aman, sosial, penghargaan, dan aktualisasi diri. Terdapat dua elemen yang mempengaruhi motivasi menurut Luthans (2006:282) yaitu motivasi motivational merupakan pendorong untuk berprestasi yang bersumber dari dalam diri seseorang atau yang sifatnya intrinsik. Motivasi higiene atau pemeliharaan merupakan faktor-faktor yang bersumber dari luar diri seseorang atau yang sifatnya ekstrinsik.

Motivasi kerja menurut Hasibuan (2005) bahwa: Motivasi kerja adalah hal yang menyebabkan, menyalurkan, dan mendukung perilaku manusia, supaya mau bekerja giat dan antusias mencapai hasil kerja yang optimal. Indikator motivasi kerja menurut McClelland (Rivai, 2011) adalah: 1) Kebutuhan prestasi (need for achievment), yang diukur dari tanggapan responden yaitu mengenai: dorongan untuk melebihi, mencapai standar-standar, berusaha keras untuk berhasil. 2) Kebutuhan kekuatan (need for power), yang diukur dari tanggapan responden yaitu mengenai kebutuhan untuk membuat individu lain berperilaku sedemikian rupa sehingga mereka tidak akan berperilaku sebaliknya. 3) Kebutuhan hubungan (need for affiliation), yang diukur dari tanggapan responden yaitu adanya keinginan untuk menjalin suatu hubungan antar personal yang ramah dan akrab.

Handoko (2010) mengemukakan stres ialah suatu kondisi ketegangan yang mempengaruhi emosi, proses berfikir dan kondisi seseorang. Stres yang terlalu besar dapat mengancam kemampuan seseorang untuk menghadapi kondisi lingkungan. 
Kepuasan kerja adalah pandangan karyawan yang menyenangkan atau tidak menyenangkan terhadap pekerjaan mereka Perasaan tersebut akan tampak dari sikap positif karyawan terhadap pekerjaan dan segala sesuatu yang dihadapi di lingkungan kerjanya" (T. Hani Handoko 2001:193). Menurut Wibowo dkk. (2015) Stres kerja berpengaruh negatif dan signifikan terhadap kepuasan kerja. Menurut Tukimin (2014) stres kerja berpengaruh negatif dan signifikan terhadap kepuasan kerja. Menurut Li Li (2014) bahwa pengaruh stress kerja terhadap kepuasan kerja berpengaruh negatif dikarenakan adanya pengembangan karir, stres upah dan imbalan yang menjadi faktor. Riaz (2016), Rizwan (2014) mengatakan bahwa stres kerja adalah masalah yang sangat substansial di tempat kerja.

$\mathrm{H}_{1}$ : stres kerja berpengaruh negatif signifikan terhadap kepuasan kerja.

Menurut Robbins dan Judge (2008) motivasi adalah keinginan untuk berusaha sekuat tenaga untuk mencapai tujuan organisasi yang dikondisikan atau ditentukan oleh kemampuan usaha untuk memenuhi suatu kebutuhan individu.

Yuswani (2016) pengaruh stres kerja terhadap motivasi berpengaruh negatif dan tidak signifikan sesuai dengan pendapat Cendhikia (2016), menurut Sumaryo (2015) bahwa stres kerja memiliki pengaruh negatif dan tidak signifikan terhadap Motivasi kerja, baik kepemimpinan menghasilkan motivasi kerja yang lebih tinggi, konflik kerja, beban kerja, waktu kerja, dan karakteristik tugas tidak mengakibatkan peningkatan kinerja dan kepemimpinan berdampak langsung positif dan signifikan terhadap kinerja serta tinggi. menurut Wani (2018) Penelitian memberikan bukti kuat adanya masalah akibat stres kerja. Stres menyebabkan berbagai masalah psikologis seperti kemarahan, depresi, kegelisahan, iritabilitas dan ketegangan dan 
ini mempengaruhi motivasi karyawan sampai batas tertentu. Menurut Widyadara (2013), pengaruh stres kerja terhadap motivasi kerja berpengaruh negatif dan signifikan. Hal ini disebabkan meningkatnya jumlah ketidakhadiran karyawan, meningkatnya jumlah keterlambatan hadir karyawan, banyaknya perilaku menyimpang ditempat kerja seperti menggunakan waktu kerja untuk mengobrol dan bermain gadget dan meningkatnya produk cacat sehingga menimbulkan ketidakpuasan konsumen.

$\mathrm{H}_{2}$ : stres kerja berpengaruh negatif dan signifikan terhadap motivasi kerja.

Robbins dan Judge (2008) motivasi adalah keinginan untuk berusaha sekuat tenaga untuk mencapai tujuan organisasi yang dikondisikan atau ditentukan oleh kemampuan usaha untuk memenuhi suatu kebutuhan individu. "Kepuasan kerja adalah pandangan karyawan yang menyenangkan atau tidak menyenangkan terhadap pekerjaan mereka Perasaan tersebut akan tampak dari sikap positif karyawan terhadap pekerjaan dan segala sesuatu yang dihadapi di lingkungan kerjanya” (T.Hani Handoko 2001:193). Menurut Kartika dan Kaihatu (2010) pengaruh motivasi kerja terhadap kepuasan kerja berpengaruh positif dan signifikan. Menurut Alamsyah (2015) Motivasi kerja yang tinggi pada karyawan ditandai dengan adanya kepuasan kerja yang tinggi. Adanya kepuasaan terhadap pekerjaan yang diekspresikan pada rasa senang terhadap pekerjaannya, menurut Jehanzeb (2012) Analisis kami menyimpulkan bahwa tingkat penghargaan, motivasi dan kepuasan kerja karyawan memiliki kekuatan hubungan di sektor perbankan Arab Saudi.

$\mathrm{H}_{3}$ : Motivasi kerja berpengaruh positif dan signifikan terhadap kepuasan kerja. 
Menurut penelitian yang dilakukan oleh Purba dan Ngatno (2016) variabel motivasi berhasil menjadi variabel pemediasi antara variabel endogen dan eksogen sejalan dengan penelitian yang dilakukan oleh Gunawan (2015) dan Widyawati (2014).

$\mathrm{H}_{4}$ : ada pengaruh motivasi sebagai pemediasi antara stres kerja terhadap kepuasan kerja

\section{METODE PENELITIAN}

Berdasarkan permasalahan yang diteliti, penelitian ini digolongkan pada penelitian asosiatif, metode ini digunakan untuk mengetahui hubungan antara stres kerja terhadapat kepuasan kerja dengan motivasi sebagai variabel mediasi. Penelitian ini dilakukan dengan penyebaran kuisioner pada pegawai PNS Badan Pendapatan Kota Denpasar, yang beralamat di jalan Letda Tantular No.12 Denpasar Timur. Dalam penelitian ini variabel mediasi (M) adalah Motivasi, dan variabel endogen (Y) adalah kepuasan kerja. Kemudian untuk variabel eksogen (X) adalah Stres kerja.

Populasi dalam penelitian ini yakni sebanyak 94 orang PNS aktif di Badan pandapatan kota denpasar. Metode penentuan sampel adalah sampling jenuh yakni teknik penentuan sampel bila semua anggota populasi digunakan sebagai sampel. Jadi sampel peserta dalam penelitian ini adalah sebanyak 94 orang.

Metode pengumpulan data dalam penelitian ini menggunakan kuisioner, wawancara, dan dokumentasi. Hasil penyebaran kuisioner yang sudah dijawab oleh responden kemudian di rekapitulasi dan diuji kelayakannya dengan menggunakan uji validitas dan uji reabilitas. Data yang sudah valid dan reliabel kemudian dianalisis lebih lanjut menggunakan analisis statistik deskriptif. Analisis statistik 
deskriptif adalah statistik yang digunakan untuk menganalisa data dengan cara mendeskripsikan atau mengambarkan data mengenai karakteristik variabel penelitian, yaitu nilai rata-rata, standar deviasi, varian, nilai minimum dan nilai maksimum (Sugiyono, 2013:207).

Teknik analisis yang digunakan dalam penelitian ini adalah teknik analisis jalur atau path analysis. Analisis jalur (path analysis) adalah perluasan dari analisis regresi linier berganda. Penelitian ini terdapat tujuh hipotesis yang kemudian disusun kedalam dua model regresi. Berikut merupakan hipotesis dan model dalam penelitian ini.

Pengujian hipotesis mediasi dalam penelitian ini dilakukan dengan Uji Sobel (Sobel Test). Uji sobel digunakan untuk menguji kekuatan pengaruh tidak langsung variabel sters kerja (X) ke variabel kepuasan kerja (Y) melalui variabel Motivasi (M). Pengaruh tidak langsung stres kerja (X) terhadap variabel kepuasan kerja (Y) melalui variabel motivasi (M) dihitung dengan mengalikan koefisien jalur $\mathrm{X}$ terhadap M (a) dengan koefisien jalur M terhadap Y (b) atau ab. Standard error koefisien a dan $\mathrm{b}$ ditulis dengan $\mathrm{S}_{\mathrm{a}}$ dan $\mathrm{S}_{\mathrm{b}}$, besarnya standard error tidak langsung (indirect effect) $\mathrm{S}_{\mathrm{ab} 1}$ dihitung dengan rumus dibawah ini:

$$
S=\sqrt{b^{2} S^{2}+a^{2} S^{2}+S^{2} S^{2}}
$$

Untuk menguji signifikansi pengaruh tidak langsung, maka dapat dilakukan dengan menghitung t dari koefisien ab dengan rumus sebagai berikut:

$$
\mathrm{Z}=\frac{a}{\mathrm{~S}}
$$




\section{HASIL DAN PEMBAHASAN}

Responden yang digunakan sebagai sampel dalam penelitian ini berjumlah 92 orang PNS di Badan Pendapatan Daerah Kota Denpasar. Responden penelitian digambarkan dengan menyajikan karakteristiknya berdasarkan variabel demografi yaitu jenis kelamin, usia, pendidikan terakhir, dan Golongan/jabatan.

Responden dalam penelitian ini adalah PNS di Badan Pendapatan Daerah Kota Denpasar di dominasi oleh responden berjenis kelamin laki-laki dengan jumlah karyawan laki-laki sebanyak 64 orang atau sebesar 69,56 persen dari total 92 orang PNS. Hal tersebut mengindikasikan bahwa Badan Pendapatan Daerah Kota Denpasar lebih didominasi oleh pegawai PNS berjenis kelamin laki-laki dari pada perempuan karena tugas setiap bidang rata-rata berada di lapangan, terutama pada bidang penagihan dan keberatan. Apabila ditinjau berdasarkan faktor usia, maka dapat dilihat bahwa PNS Badan Pendapatan Daerah Kota Denpasar mayoritas memiliki usia antara 40 sampai 49 tahun. Kelompok usia tersebut merupakan kelompok usia yang masih tergolong produktif. Faktor usia seorang karyawan dapat menunjang kegiatan organisasi dalam menghasilkan organisasi yang berkualitas.

Data responden yang diperoleh dari hasil kuesioner yang telah disebar berdasarkan tingkat pendidikan menunjukkan mayoritas PNS Badan Pendapatan Daerah Kota Denpasar adalah kelompok responden dengan tingkat pendidikan Sarjana dengan jumlah sebanyak 60 orang atau sebesar 65,22 persen. Informasi ini memberikan gambaran bahwa PNS Badan Pendapatan Daerah Kota Denpasar paling dominan berpendidikan terakhir Sarjana dan dianggap sudah mampu serta 
memadai untuk menjadi karyawan PNS yang memiliki kompetensi untuk mencapai tujuan perusahaan.

Pengelompokkan responden berdasarkan golongan bahwa responden yang memiliki golongan III (a/b/c) sebanyak 65 orang atau sebesaar 70,65 persen Hal ini mengindikasikan bahwa responden didominasi oleh jenjang pendidikan yang tinggi yaitu sarjana yang dianggap mampu menjadi pegawai yang siap berkarir dan memiliki kompetensi.

Hasil uji validitas instrumen penelitian disajikan pada Tabel berikut yang menunjukkan bahwa seluruh indikator pertanyaan dalam variabel stres kerja, motivasi, dan kepuasan kerja memiliki nilai Pearson Correlation yang lebih besar dari angka 0,30 sehingga seluruh indikator tersebut telah memenuhi syarat validitas data.

Tabel 2.

Hasil Uji Validitas Instrumen

\begin{tabular}{|c|c|c|c|}
\hline Variabel & Instrumen & Pearson Correlation & Keterangan \\
\hline \multirow{5}{*}{$\begin{array}{l}\text { Stres Kerja } \\
\text { (X1) }\end{array}$} & X.1 & 0,707 & Valid \\
\hline & X.2 & 0,390 & Valid \\
\hline & X.3 & 0,435 & Valid \\
\hline & X.4 & 0,732 & Valid \\
\hline & X.5 & 0,304 & Valid \\
\hline \multirow{6}{*}{$\begin{array}{l}\text { Motivasi } \\
\text { (M) }\end{array}$} & M.1 & 0,362 & Valid \\
\hline & M.2 & 0,438 & Valid \\
\hline & M.3 & 0,325 & Valid \\
\hline & M.4 & 0,586 & Valid \\
\hline & M.5 & 0,352 & Valid \\
\hline & M.6 & 0,603 & Valid \\
\hline \multirow{6}{*}{$\begin{array}{l}\text { Kepuasan Kerja } \\
\text { (Y) }\end{array}$} & Y.1 & 0,385 & Valid \\
\hline & Y.2 & 0,347 & Valid \\
\hline & Y.3 & 0,851 & Valid \\
\hline & Y.4 & 0,418 & Valid \\
\hline & Y.5 & 0,521 & Valid \\
\hline & Y.6 & 0,357 & Valid \\
\hline
\end{tabular}

Sumber: Data diolah, 2018

Uji reliabilitas bertujuan untuk mengetahui sejauh mana alat ukur dapat dipercaya atau dapat diandalkan. Pengujian reliabilitas dilakukan terhadap 
instrumen dengan koefisien cronbach's alpha. Apabila nilai cronbach's alpha lebih besar dari 0,60 maka instrumen yang digunakan reliabel. Hasil uji reliabilitas instrumen pada penelitian ini disajikan pada tabel berikut yang menunjukkan bahwa ketiga instrumen penelitian yaitu stres kerja, motivasi, dan kepuasan kerja memiliki koefisien cronbach's alpha yang lebih besar dari angka 0,60 sehingga pernyataan pada kuesioner tersebut dapat dikatakan reliabel.

Tabel 3.

Hasil Uji Reliabilitas Instrumen Penelitian

\begin{tabular}{ccc}
\hline Variabel & Cronbach'sAlpha & Keterangan \\
\hline Stres Kerja $(\mathrm{X})$ & 0,644 & Reliabel \\
Motivasi $(\mathrm{M})$ & 0,620 & Reliabel \\
Kepuasan Kerja $(\mathrm{Y})$ & 0,631 & Reliabel \\
\hline
\end{tabular}

Sumber: Data diolah, 2018

Pengujian data dalam penelitian ini menggunakan teknik analisis jalur (Path Analysis), dimana analisis jalur adalah perluasan dari analisis regresi linear berganda untuk menguji hubungan kausalitas antara 2 atau lebih variabel. Perhitungan koefisien path dilakukan dengan analisis regresi melalui software SPSS 22.0 for Windows, diperoleh hasil yang ditunjukan pada Tabel 4 berikut.

Tabel 4.

Hasil Analisis Jalur Persamaan Regresi 1

\begin{tabular}{cccc}
\hline Model & R Square & $\begin{array}{c}\text { Standardized Coefficients } \\
\text { Beta }\end{array}$ & Sig. \\
\hline Stres Kerja & 0,394 & $-0,264$ & 0,118 \\
\hline
\end{tabular}

Sumber: Data diolah, 2018

Berdasarkan hasil analisis jalur substruktural 1 yang disajikan pada tabel di atas, maka persamaan strukturalnya adalah sebagai berikut:

$$
M=-0,264 X+e_{1}
$$

Besarnya pengaruh variabel bebas terhadap variabel terikat yang ditunjukkan oleh nilai determinasi total (R Square) sebesar 0,394 mempunyai arti bahwa sebesar 
39,4\% variasi kepuasan kerja dipengaruhi oleh variasi stres kerja, sedangkan sisanya sebesar $60,6 \%$ dijelaskan oleh faktor lain yang tidak dimasukkan ke dalam model.

Tabel 5.

Hasil Analisis Jalur Persamaan Regresi 2

\begin{tabular}{cccc}
\hline & & Standardized Coefficients \\
Model & R Square & Beta & Sig. \\
\hline Stres Kerja & 0,593 & $-0,341$ & 0,001 \\
Motivasi & & 0,398 & 0,022 \\
\hline Sumber: Data diolah, 2018 & &
\end{tabular}

Berdasarkan hasil analisis jalur substruktural 2 yang disajikan pada tabel di atas, maka persamaan strukturalnya adalah sebagai berikut:

$$
\mathrm{Y}=-0,341 \mathrm{X}+0,398 \mathrm{M}+\mathrm{e}_{2}
$$

Menguji variabel error (e) dan nilai koefisien determinasi total $\left(\mathrm{R}^{2} \mathrm{~m}\right)$

Berdasarkan model substruktural 1 dan substruktural 2, maka dapat disusun model diagram jalur akhir. Sebelum menyusun model diagram jalur akhir, terlebih dahulu dihitung nilai standar eror sebagai berikut:

$$
\begin{aligned}
& \mathrm{Pei}=\sqrt{1-\mathrm{Ri}^{2}} \\
& \mathrm{Pe}_{1}=\sqrt{1-\mathrm{R}_{1}{ }^{2}}=\sqrt{1-0,394^{2}}=0,919 \\
& \mathrm{Pe}_{2}=\sqrt{1-\mathrm{R}_{2}{ }^{2}}=\sqrt{1-0,593^{2}}=0,805
\end{aligned}
$$

Berdasarkan perhitungan nilai standar eror, didapatkan hasil $\mathrm{Pe}_{1}$ atau standar eror variabel motivasi sebesar 0,919 dan $\mathrm{Pe}_{2}$ atau standar eror variabel kepuasan kerja sebesar 0,805. Hasil koefisien determinasi total dihitung sebagai berikut:

$$
\begin{aligned}
\mathrm{R}^{2} \mathrm{~m} & =1-\left(\mathrm{Pe}_{1}\right)^{2}\left(\mathrm{Pe}_{2}\right)^{2} \\
& =1-(0,919)^{2}(0,805)^{2} \\
& =0,453
\end{aligned}
$$


Nilai determinasi total sebesar 0,453 mempunyai arti bahwa sebesar 45,3\% variasi kepuasan kerja dipengaruhi oleh variasi stres kerja dan motivasi, sedangkan sisanya sebesar 54,7\% dijelaskan oleh faktor-faktor lain yang tidak dimasukkan ke dalam model.

Besarnya pengaruh langsung dan tidak langsung serta pengaruh total antar variabel dirangkum dalam Tabel 4 sebagai berikut.

\section{Tabel 4}

\begin{tabular}{|c|c|c|c|}
\hline \multicolumn{4}{|c|}{$\begin{array}{c}\text { Pengaruh Langsung dan Pengaruh Tidak Langsung serta Pengaruh Total } \\
\text { Stres kerja (X), Motivasi (M), dan Kepuasan Kerja(Y) }\end{array}$} \\
\hline Pengaruh Variabel & $\begin{array}{l}\text { Pengaruh } \\
\text { Langsung }\end{array}$ & $\begin{array}{l}\text { Pengaruh Tidak Langsung } \\
\text { Melalui Mediasi }\left(\beta_{1} \times \beta_{3}\right)\end{array}$ & Pengaruh Total \\
\hline$X \rightarrow M$ & 0,264 & - & 0,264 \\
\hline$X \rightarrow Y$ & 0,341 & 0,105 & 0,446 \\
\hline $\mathrm{M} \rightarrow \mathrm{Y}$ & 0,398 & - & 0,398 \\
\hline
\end{tabular}

Berdasarkan Tabel 4 dapat disimpulkan bahwa stres kerja memiliki pengaruh langsung terhadap kepuasan kerja dan pengaruh tidak langsung melalui motivasi. Hasil koefisien pengaruh tidak langsung lebih kecil diabandingkan pengaruh langsung $(0,105<0,341)$, sehingga dapat dikatakan bahwa variabel motivasi adalah sebagai variabel mediasi dalam memediasi pengaruh variabel stres kerja tehadap variabel kepuasan kerja.

Berdasarkan hasil analisis pengaruh stres kerja terhadap kepuasan kerja, diperoleh hasil bahwa stres kerja berpengaruh negatif dan signifikan terhadap kepuasan kerja. Ini berarti semakin tinggi tingkat stress di kalangan pegawai PNS Badan Pendapatan Daerah Kota Denpasar maka semakin rendah tingkat kepuasan kerja yang dirasakan pegawai. Begitu juga sebaliknya semakin rendah tingkat stres di kalangan pegawai PNS Badan Pendapatan Daerah Kota Denpasar maka semakin 
tinggi tingkat kepuasan kerja pegawai. Penelitian ini sejalan dengan penelitian yang sudah dilakukan oleh Wibowo dkk. (2015), Tukimin (2014), Li Li (2014), Riaz (2016), Rizwan (2014) mengatakan bahwa stres kerja berpengaruh negative dan signifikan terhadap kepuasan kerja.

Berdasarkan hasil analisis pengaruh stres kerja terhadap motivasi, diperoleh hasil bahwa stres kerja berpengaruh negatif dan signifikan terhadap motivasi. Ini berarti semakin tinggi stress kerja pegawai PNS pada Badan Pendapatan Daerah Kota Denpasar maka semakin rendah tingkat motivasi pegawai, sebaliknya semakin rendah tingkat stress kerja pegawai pada Badan Pendapatan Daerah Kota Denpasar maka semakin tinggi tingkat motivasi pegawai. Menurut Wani (2018) stress kerja menyebabkan berbagai masalah psikologis seperti kemarahan, depresi, kegelisahan, iritabilitas dan ketegangan dan ini mempengaruhi motivasi karyawan sampai batas tertentu. Hasil penelitian ini sejalan dengan penelitian yang telah dilakukan oleh Yuswani(2016), Cendhikia (2016), Sumaryo (2015), Widyadara (2013) Wani (2018) yang menyatakan bahwa pengaruh stres kerja terhadap motivasi kerja berpengaruh negatif dan tidak signifikan.

Berdasarkan hasil analisis pengaruh motivasi terhadap kepuasan kerja, diperoleh hasil bahwa motivasi berpengaruh positif dan signifikan terhadap kepuasan kerja. Ini berarti bahwa semakin tinggi tingkat motivasi karyawan PNS pada Badan Pendapatan Daerah Kota Denpasar makan semakin tinggi pula kepuasan kerja yang dirasakan pegawai. Alamsyah (2015) Motivasi kerja yang tinggi pada karyawan ditandai dengan adanya kepuasan kerja yang tinggi. Adanya kepuasaan terhadap pekerjaan yang diekspresikan pada rasa senang terhadap 
pekerjaannya. Hasil penelitian ini sejalan dengan penelitian yang telah dilakukan oleh Kartika dan Kaihatu (2010), Jehanzeb (2012) Khalid (2011), Li Li (2017) bahwa motivasi berpengaruh positif dan signifikan terhadap kepuasan kerja.

Berdasarkan uji sobel diperoleh hasil bahwa motivasi mampu memediasi pengaruh stres kerja terhadap kepuasan kerja. Ini berarti bahwa karyawan PNS yang mampu menekan stres kerjanya akan terdorong untuk meningkatkan motivasinya dan dengan meningkatnya rasa motivasinya tersebut maka akan meningkatkan kepuasan kerja karyawan PNS. Motivasi secara positif dan signifikan memediasi pengaruh stres kerja terhadap kepuasan kerja PNS pada Badan Pendapatan Daerah Kota Denpasar memiliki makna bahwa meskipun adanya stres kerja tetapi apabila ditunjang dengan motivasi yang tinggi maka akan timbul kepuasan kerja yang maksimal.

Penelitian ini menghasilkan informasi bahwa motivasi berpengaruh positif terhadap kepuasan kerja dengan nilai $\beta_{3}$ sebesar 0,398 . Nilai dari pengaruh motivasi terhadap kepuasan kerja memiliki pengaruh tertinggi, hal ini menjadikan bahan pertimbangan bagi Badan Pendapatan Daerah Kota Denpasar untuk lebih meningkatkan motivasi para pegawai PNS karena motivasi memainkan peranan penting untuk meingkatkan kepuasan kerja. Tanda positif merupakan adanya hubungan searah antara motivasi dengan kepuasan kerja, semakin tinggi motivasi yang diperoleh karyawan baik dari rekan kerja ataupun dari dalam diri karyawan itu sendiri maka semakin tinggi pula kepuasan kerja yang dirasakan oleh karyawan. Hal ini sesuai dengan penelitian yang telah dilakukan oleh Kartika (2010), Alamsyah (2015), jehanzeb (2012), Khalid (2011), Li Li (2017). 
Stress kerja berpengaruh negatif terhadap motivasi kerja dengan nilai $\beta_{1}$ sebesar -0,264. Tanda negatif menunjukkan adanya hubungan yang berbanding terbalik antara stress kerja dengan motivasi, semakin rendah stress kerja yang dirasakan oleh karyawan maka semakin tinggi tingkat motivasi karyawan untuk bekerja. Hal ini menunjukkan bahwa stress kerja perlu ditekan agar motivasi dapat ditingkatkan pada Badan Pendapatan Daerah Kota Denpasar. Penelitian ini sesuai dengan pendapat Cendhikia (2016), Yuswani (2016), Sumaryo (2015), Widyadara (2013).

Stress kerja berpengaruh negatif terhadap kepuasan kerja dengan nilai $\beta_{2}$ sebesar $-0,341$. Tanda negatif menunjukkan adanya hubungan berbanding terbalik antara stress kerja dengan kepuasan kerja, semakin rendah stress kerja yang dirasakan oleh karyawan maka semakin tinggi tingkat kepuasan kerja yang dirasakan karyawan. Hal ini meunjukkan bahwa stress kerja perlu ditekan untuk meningkatkan kepuasan kerja yang dirasakan oleh pegawai PNS Badan Pendapatan Daerah Kota Denpasar. Penelitian ini sesuai dengan pendapat Handoko (2010), Wibowo dkk. (2015), Tukimin (2014), Li Li (2014), Riaz (2016), Rizwan (2014).

\section{SIMPULAN DAN SARAN}

Berdasarkan hasil analisis penelitian dan hasil pembahasan pada bab sebelumnya maka simpulan dari penelitian ini adalah Stres kerja berpengaruh negatif dan signifikan terhadap kepuasan kerja. Ini berarti semakin tinggi tingkat stress di kalangan pegawai PNS Badan Pendapatan Daerah Kota Denpasar maka semakin rendah tingkat kepuasan kerja yang dirasakan pegawai. Stres kerja berpengaruh negatif dan signifikan terhadap motivasi. Ini berarti semakin tinggi 
stress kerja pegawai PNS pada Badan Pendapatan Daerah Kota Denpasar maka semakin rendah tingkat motivasi pegawai. Motivasi berpengaruh positif dan signifikan terhadap kepuasan kerja. Ini berarti bahwa semakin tinggi tingkat motivasi karyawan PNS pada Badan Pendapatan Daerah Kota Denpasar makan semakin tinggi pula kepuasan kerja yang dirasakan pegawai. Motivasi mampu memediasi pengaruh stres kerja terhadap kepuasan kerja. Ini berarti bahwa meskipun adanya stres kerja tetapi apabila ditunjang dengan motivasi yang tinggi maka akan timbul kepuasan kerja yang maksimal.

Saran yang dapat dipergunakan sebagai bahan pertimbangan antara lain Bagi Organisasi: Dari hasil penelitian pada variabel kepuasan kerja didapat nilai rata-rata terendah hasil jawaban responden terdapat pada pernyataan ke 3 "Mengejar karir atau jabatan menjadi tujuan anda dalam bekerja" dengan nilai rata-rata 3,50. Hal ini menunjukkan bahwa keingininan untuk mengejar karir dalam pekerjaan pada Badan Pendapatan Daerah Kota Denpasar cenderung rendah, oleh sebab itu perlu adanya arahan dari pimpinan kepada pegawai untuk melanjutkan pendidikan yang akan menunjang kenaikan jabatan. Dari hasil penelitian pada variabel stres kerja didapat nilai rata-rata terendah terdapat pada pernyataan pertama yaitu "Anda diberikan tugas berlebihan disertai dengan batas waktu yang ditentukan" dengan nilai rata-rata 3,42. Ini berarti bahwa pegawai pada Badan Pendapatan Daerah Kota Denpasar cenderung tidak diberikan rentan waktu yang mengikat dalam menyelesaikan tugas, walaupun tidak adanya rentan waktu yang mengikat dalam menyelesaikan tugas hendaknya para pegawai tetap menyelesaikan tugas yang diberikan tepat pada waktunya. Dari hasil penelitian pada variabel motivasi didapat 
nilai rata-rata terendah terdapat pada pernyataan kedua "Saya memiliki rasa percaya diri dalam melaksanakan tugas untuk diselesaikan", dengan nilai rata-rata sebesar 4,01. Hal ini mengindikasikan bahwa pegawai PNS badan pendapatan daerah Kota denpasar lebih menyadari batas kemampuan diri dalam menyelesaikan tugas sehingga belum timbulnya rasa yakin dalam diri sendiri. Perlu adanya motivasi untuk meningkatan rasa percaya diri yang bersumber baik dari atasan kepada bawahan maupun dari sesama rekan kerja.

Saran Bagi peneliti selanjutnya agar lebih memperluas ruang lingkup penelitian dan tidak hanya menggunakan variabel stres dan motivasi yang mempengaruhi kepuasan kerja. Bagi karyawan PNS agar dapat memotivasi diri sendiri selain memperoleh motivasi dari atasan yang berguna untuk menekan stres dan meningkatkan kepuasan kerja, sehingga dapat bekerja tanpa tekanan dan mencapai hasil yang maksimal dalam bekerja.

\section{REFERENSI}

Adelia dan Mujiati, (2016). Pengaruh Kompensasi, Gaya Kepemimpinan Dan Stres Kerja Terhadap Kepuasan Kerja Karyawan Di Rs Dharma Kerti. Fakultas Ekonomi dan Bisnis Universitas Udayana, Bali, Indonesia. E-Jurnal Manajemen Unud, 4(1):102-105.

Afrizal, Al musadieq, Ruhana, (2014). Pengaruh Konflik Kerja Dan Stres Kerja Terhadap Kepuasan Kerja (Studi pada Karyawan PT. TASPEN (Persero Cabang Malang). Jurnal Administrasi Bisnis (JAB), 8(1): 220-225.

Ahsan, Abdullah, Gun fie, Alam, (2009). A Study of Job Stress on Job Satisfaction among University Staff in Malaysia: Empirical Study. European Journal of Social Sciences, 8(1): 135-139.

Ayu, Ida Brahmasari dan Suprayetno, Agus. (2008). Pengaruh Motivasi Kerja, Kepemimpinan dan Budaya Organisasi Terhadap Kepuasan Kerja Karyawan serta Dampaknya pada Kinerja Perusahaan (Studi kasus pada PT. Pei Hai International Wiratama Indonesia). Jurnal Manajemen dan Kewirausahaan, 10(2): 89-96. Surabaya: Universitas 17 Agustus 
Cahyono, Ari. (2012). Analisis Pengaruh Kepemimpinan, Motivasi dan Budaya Organisasi terhadap Kinerja Dosen Dan Karyawan Di Universitas Pawyatan Daha Kediri'. Jurnal Ilmu Manajemen Revitalisasi Universitas Pawyatan Daha Kediri. 1(1):283 - 298,

Dewi dan Netra, (2015). Pengaruh Stres Kerja Dan Motivasi Kerja Terhadap Kepuasan Kerja Karyawan Pada Matahari Bungalow Restaurant and Spa Legian Kuta-Bali. Fakultas Ekonomi dan Bisnis Universitas Udayana (Unud), Bali, Indonesia. E-Jurnal Manajemen Unud, 4(6): 98-105.

Essiam, (2015). Commerce And Management. Influence Of Job Stress On Job Satisfaction Among University Staff: Analytical Evidence From A Public University In Ghana. International Journal Of Economics, 4(2); 1-15.

Luthans, Fred, (2011). Organizational Behavior; an Evidence - Based approach, New York : the MacGrow - Hill Companies.inc.

Gunawan. (2015). Pengaruh Kompetensi Terhadap Kinerja Pegawai dan Motivasi Sebagai Variabel Intervening Pada Kantor Uptd Pendapatan Wilayah I Palu. e-Jurnal Katalogis, 3 (1):75-83.

Hanim, (2016). Pengaruh Stres Kerja Terhadap Kepuasan Kerja Serta Dampaknya Pada Kinerja Karyawan Hull Construction Di PT. Dok Dan Perkapalan Surabaya. Fakultas Ekonomi, Universitas Negeri Surabaya, Jurnal Ilmu Manajemen, 4(2):110-115.

Hasibuan, Malayu S.P (2005). Fungsi manajemen SDM. Jilid 1 Jakarta.

Handoko.L.T, (2005). International journal. FISIKALIPI-05002 .Scientific and Financial Performance Measure : A Simultaneous Model to Evaluate Scientific Activities.

Jehanzeb. (2010). Impact of Rewards and Motivation on Job Satisfaction in Banking Sector of Saudi Arabia. International Journal of Business and Social Science. 3(1): 150-161.

Kartika dan Kaihatu, (2010). Analisis Pengaruh Motivasi Kerja Terhadap Kepuasan Kerja (Studi Kasus pada Karyawan Restoran di Pakuwon Food Festival Surabaya). Program Manajemen Perhotelan, Fakultas Ekonomi, Universitas Kristen Petra, 8(1): 346-349. Jurnal Manajemen Dan Kewirausahaan, Vol.12

Khalid, (2011). The Impact of Rewards and Motivation on Job Satisfaction in Water Utility Industry . International Journal on Financial Management and Economics, 11(1): 255-260. 
Kreitner, Robert dan Angelo Kinicki. (2001). Perilaku Organisasi. Jilid 1 Jakarta: Salemba Empat.

Li li, (2014). Work Stress, Work Motivation And Their Effects On Job Satisfaction In Community Health Workers: A Cross-Sectional Survey In China. BMJ Open journal. 4(1):1- 9.

Luthans, F. (2006). Perilaku Organisasi. Edisi Sepuluh. Yogyakarta : ANDI.

Mansoor, (2011). The Impact Of Job Stress On Employee Job Satisfaction A Study On Telecommunication Sector Of Pakistan. Journal of Business Studies Quarterly. Volume 2(1): 201-205.

Iqbal and Adnan waseem , (2013). Impact of Job Stress on Job Satisfaction among Air Traffic Controllers of Civil Aviation Authority: An Empirical Study from Pakistan .International Journal of Human Resource Studies ISSN 2162-3058 2012, Vol. 2(2): 93-99.

Noviansyah dan Zunaidah, (2011). Jurnal Manajemen dan Bisnis Sriwijaya 9(18): 35-43. Pengaruh Stres Kerja Dan Motivasi Kerja Terhadap Kinerja Karyawan PT. Perkebunan Minanga Ogan Baturaja.

Panchanatham and Sowmya, (2011). Factors influencing job satisfaction of banking sector employees in Chennai, India. Journal of Law and Conflict Resolution 3(5):76-79.

Purba dan Ngatno. (2015). Pengaruh Peran Pemimpin Terhadap Kinerja Karyawan Melalui Motivasi Sebagai Variabel Intervening. Jurnal Ilmu Administrasi Bisnis. Volume 5(4): 105-107.

Riaz, (2016). Impact of Job Stress on Employee Job Satisfaction. Government Post graduate College Sahiwal, Pakistan. Irmb journal. 5(2): 119-123.

Robbins, (2015). Perilaku Organisasi. Edisi 16. Jakarta : Salemba Empat.

Robbins, Stephen P. \& Timothy A. Judge. (2009). Organizational Behavior. Thirteenth Edition. New Jersey: Pearson Prentice Hall.

Robbins SP, dan Judge. (2007). Perilaku Organisasi, Salemba Empat, Jakarta.

Robbins, Stephen P. \& Timothy A. Judge. (2008). Essential of Organizational Behavior. Ninth Edition. New Jersey: Pearson Prentice Hall. 
Saleem, (2010). Effect Of Work Motivation On Job Satisfaction In Mobile Telecommunication Service Organizations Of Pakistan. International Journal of Business and Management. 5(3): 221-225.

Salleh, A. L., Bakar, R. A., Keong, W. K.(2008). How Detrimental is Job Stress? : A Case Study Of Executives in the Malaysian Furniture Industry. International Review of Business Research Papers, 4(5): 109-118.

Sumaryo, (2015). Effects of Job Stress, Leadership on Motivation and Members of Parliament of the Regional House of Representatives Performance. International Journal of Humanities and Social Science Invention. Volume 4(6):49-54.

Tunjungsari, (2011), Pengaruh Stress Kerja Terhadap Kepuasan Kerja Karyawan Pada Kantor Pusat Pt. Pos Indonesia (Persero) Bandung. Universitas Komputer Indonesia. 5(1):59-65.

Tukimin. (2014). Pengaruh Stres Kerja Terhadap Kepuasan Kerja Pada Dinas Pertanian Sumatera Utara. Kultura. Volume: 15(1): 123-126.

Wani. (2013). Job stress and its impact on employee motivation: a study of a select commercial bank. International Journal of Business and Management Invention. 2(3):13-18.

Widyawati, Titis. (2014). Pengaruh Gaya Kepemimpinan terhadap Kinerja Karyawan dengan Motivasi sebagai Variabel Intervening. Jurnal Ilmu dan Riset Manajemen 3(3): 93-100.

Wibowo Gede, Riana Gede, Surya putra, (2015). Pengaruh Stres Kerja Terhadap Kepuasan Kerja dan Komitmen Organisasional Karyawan. E-Jurnal Ekonomi dan Bisnis Universitas Udayana.5(1): 86-90.

Yuswani, (2016), Jurnal Sainstech Politeknik Indonusa Surakarta. Pengaruh Budaya Organisasi Dan Stres Terhadap Motivasi Kerja Dan Dampaknya Terhadap Kinerja Karyawan Pada Pt. Kerinci Permata Motor Jambi. Politeknik Indonusa Surakarta. 2(1): 59-66. 